\title{
PERKEMBANGAN PENDIDIKAN ISLAM DAN HUMANISASI DI GORONTALO AWAL ABAD KE-20
}

\author{
Mursalat Kulap \\ Universitas Sebelas Maret, Surakarta, Indonesia \\ mursalatkulap@gmail.com \\ Laili Masithoh Hamdiyah \\ Universitas Sebelas Maret, Surakarta, Indonesia \\ lailimasithohhamdiyah@gmail.com \\ Renol Hasan \\ Universitas Negeri Gorontalo, Gorontalo, Indonesia \\ renoldhasan@ung.ac.id
}

\begin{abstract}
THE DEVELOPMENT OF ISLAMIC EDUCATION AND HUMANIZATION IN GORONTALO IN EARLY 20th CENTURY. This research aims to explain the development of Islamic education and its role in the process of humanization in Gorontalo in early 20th century. The presented explanation is the historical explanation, so the method used in this research is the historical research method with research measures: heuristic, sources verification, interpretation, and historiography. The results showed that the development of Islamic education in Gorontaloin early 20th century was very rapid and motivated by three things: firts, access to education, transportation, and more open information; second, the internal view of Islam itself about the importance of science; and third, as a response of to the massive spread of christianity by the Dutch colonial goverment. The existence of Islamic schools has given a great contribution to humanity. The increasing number of schools established by Islamic organizations in Gorontalo, has provided the opportunity for indigenous groups to acquire education. The implication of all is the formation of consciousness of Gorontalo society about the importance of the human
\end{abstract}


equality, so at the next development was born the elite of Gorontalo which fight for independence through the Islamic organizations as a form of the humanization.

Keywords : Islamic Education, Humanization, Gorontalo

\begin{abstract}
Abstrak
PERKEMBANGAN PENDIDIKAN ISLAM DAN HUMANISASI DI GORONTALO AWAL ABAD KE-20. Penelitian ini bertujuan mengeksplanasikan perkembangan pendidikan Islam dan perannya dalam proses humanisasi di Gorontalo awal abad ke-20. Eksplanasi yang dihadirkan adalah eksplanasi sejarah, sehingga metode yang digunakan dalam penelitian ini adalah metode sejarah dengan langkah-langkah penelitian yakni heuristik, verifikasi sumber, interpretasi, dan historiografi. Hasil penelitian menunjukkan bahwa perkembangan pendidikan Islam di daerah Gorontalo pada awal abad XX sangat pesat dan dilatarbelakangi oleh 3 hal yakni pertama akses pendidikan, transportasi dan informasi yang semakin terbuka, kedua pandangan internal dari Islam itu sendiri tentang pentingnya ilmu, dan ketiga sebagai respon terhadap masifnya penyebaran agama Kristen oleh pemerintah kolonial Belanda. Keberadaan sekolah-sekolah Islam memberikan kontribusi besar dalam kemanusiaan. Semakin banyaknya sekolah-sekolah yang didirikan oleh organisasi-organisasi Islam di Gorontalo, telah memberikan kesempatan kepada kelompok pribumi untuk memperoleh pendidikan. Implikasi dari semua itu adalah terbentuknya kesadaran masyarakat Gorontalo tentang arti penting persamaan derajat manusia, sehingga pada perkembangan selanjutnya lahirlah elit-elit lokal Gorontalo yang memperjuangkan kemerdekaan melalui organisasi-organisasi Islam sebagai bentuk proses humanisasi.
\end{abstract}

Kata Kunci : Pendidikan Islam, Humanisasi, Gorontalo

\title{
A. Pendahuluan
}

Pendidikan Islam di Indonesia telah mengalami perjalanan sejarah yang cukup panjang, bahkan menjadi salah satu instrumen penting dalam penyebaran Islam. Pendidikan Islam masih tetap eksis sampai dengan sekarang dan bahkan menjadi salah satu solusi dalam menghadapi derasnya arus jaman yang semakin menjauh dari nilai-nilai moral. Pendidikan Islam merupakan salah 
satu bagian yang dianggap penting di tengah-tengah masyarakat Indonesia yang pada dasarnya merupakan komunitas Islam terbesar di dunia. Sehingga tidak begitu mengherankan ketika ditemukan sekolah-sekolah Islam - baik yang menggunakan kurikulum secara umum maupun yang spesifik - di sebagian besar wilayah Indonesia. Sebelum membahas lebih jauh tentang pendidikan Islam terutama dalam perspektif sejarah, perlu terlebih dahulu dijelaskan konsepsi pendidikan Islam agar bisa mendefenisikan pendidikan Islam tersebut dalam satu perspektif.

Menurut an-Nahlawy sebagaimana di kutip Huda, pendidikan Islam merupakan sistem pendidikan yang bertujuan untuk melatih peserta didik agar nilai-nilai spiritual dan etika Islam senantiasa menjadi rujukan dalam sikap hidup, tindakan, dan bahkan sampai pada pendekatan dalam pengetahuan (Huda, 2015: 171). Secara pemaknaannya, filsafat pendidikan Islam tidak jauh berbeda dengan pendidikan umum, hanya saja pendidikan Islam menggunakan Alquran dan sunnah sebagai dasar dan sekaligus sumber rujukan (Mustaghfiroh, 2015: 95). Pendidikan Islam juga dipandang sebagai sebuah pendekatan dalam mencapai tingkatan amal dan ilmu yang paripurna. Artinya bahwa pendidikan Islam diarahkan pada penggalian potensi-potensi positif dari manusia, dan juga sebaliknya yakni penekanan terhadap potensipotensi negatif (Rahmad dalam Rohmah, 2014: 355). Selain itu, pendidikan Islam juga berorientasi pada kemanusiaan. Iqbal sebagaimana dikutip Kurniawan dan Mahrus mengatakan bahwa pendidikan Islam berorientasi pada pembentukan insan saleh dan masyarakat saleh, menciptakan keserasian dalam kehidupan (Kurniawan dan Mahrus, 2013: 145). Pendek kata, pendidikan Islam juga berkepentingan dalam proses humanisasi.

Jika dikategorikan dalam sebuah institusi, maka pendidikan Islam dapat dirincikan menjadi 4 bagian yakni:

Pertama, pondok pesantren, ialah pendidikan Islam yang diselengarakan secara tradisional, bertolak dari pengajaran Quran dan hadits, dan merancang segenap kegiatan pendidikannya untuk mengajarkan kepada para siswa Islam sebagai cara hidup, sebagai way of life. Kedua, Pendidikan sekolah, ialah pendidikan Islam yang diselenggarakan di lembaga-lembaga pendidikan 
model Barat, yang mempergunakan metode pengajaran klasikal, dan berusaha menanamkan Islam sebagai landasan hidup ke dalam diri para siswa. Ketiga, Pendidikan umum yang bernafaskan Islam ialah pendidikan Islam yang diselenggarakan melalui pengembangan suasana pendidikan yang bernafaskan Islam di lembaga-lembaga pendidikan yang menyelenggarakan program pendidikan yang bersifat umum; dan keempat, pelajaran agama Islam yang diselenggarakan di lembaga-lembaga pendidikan umum sebagai suatu mata pelajaran atau mata kuliah saja (Bukhari dalam Masduki, 2015 : 263 - 264).

Dengan demikian, maka dapat dikonstruksi sebuah pemahaman bahwa pendidikan Islam merupakan sebuah proses transfer of knowledge dan juga sekaligus transfer of values yang berdasarkan pada Alquran, Sunnah, dan hadis. Hal ini bertujuan untuk memperoleh keseimbangan antara ilmu pengetahuan dan amal dalam praktek kehidupan sehari-hari. Pendidikan Islam juga berorientasi pada penciptaan tatanan kehidupan manusia yang berkeadaban. Secara institusional, penyelenggaraan pendidikan Islam di Indonesia mengalami perkembangan dari sistem tradisional menjadi modern.

Dalam perspektif sejarah, pendidikan Islam di Indonesia telah dimulai sejak periode awal penyebaran Islam, meskipun sistemnya masih tradisional. Kuntowijoyo (1991: 57) mengatakan bahwa tipe awal pendidikan Islam yang ada di Indonesia adalah pondok pesantren, yang merupakan bagian dari adaptasi Islam terhadap lembaga sejenisnya pada masa sebelumnya yakni HinduBudha. Pesantren biasanya dimiliki oleh seorang kiai, baik pondok, masjid, dan kekayaan lainnya. Kemudian pada periode tahun 1920-an, pendidikan Islam mulai mengadopsi sistem madrasah (sistem kelas) yang sama dengan sistem yang diberlakukan pada pendidikan umum saat itu.

Pada periode awal abad XX, pendidikan Islam bertransformasi menjadi sebuah kekuatan besar dan lebih terorganisir dalam gerakan-gerakan perlawanan terhadap kolonialisme Belanda. Wilayah penyebaran sekolah-sekolah Islam semakin meluas, tidak hanya di wilayah pulau Jawa, melainkan juga ke daerah-daerah lainnya seperti di Gorontalo. Perkembangan 
pendidikan Islam di Indonesia (khususnya Gorontalo) memberikan kontribusi terhadap munculnya elit lokal Gorontalo yang kemudian menjadi protagonis dalam proses humanisasi melalui organisasi-organisasi Islam. Pendidikan berbasis pada agama Islam disebarkan sampai ke lapisan masyarakat yang tidak terjamah pendidikan barat saat itu. Pendidikan (termasuk pendidikan Islam) telah menjadi instrumen penting dalam proses penyadaran diri manusia. Menurut Freire (1985: 27) bahwa pendidikan merupakan proses humanisasi dan pembebasan dari praktek-praktek penindasan. Proses awal pendidikan berada pada tahap penyadaran diri tentang adanya penindasan, dan tahap selanjutnya adalah proses perlawanan terhadap praktek penindasan tersebut.

Berdasarkan latar belakang di atas, maka sangat menarik untuk mengulas bagaimana perkembangan pendidikan Islam dan juga perannya dalam proses humanisasi di Gorontalo pada periode awal abad XX? Humanisasi yang dimaksud dalam penelitian ini adalah proses perjuangan pribumi Gorontalo untuk mendapatkan pengetahuan dan selanjutnya menciptakan perkembangan kemanusiaan. Perjuangan tersebut berimpak pada munculnya gerakan-gerakan untuk melepaskan diri dari praktek kolonialisme di awal abad ke-20. Adapun metode penelitian yang digunakan adalah metode penelitian sejarah yang terdiri dari langkahlangkah sebagai berikut: Pertama, heuristik, yang merupakan tahap pengumpulan sumber. Pada tahap ini kemampuan teoriteori yang bersifat deduktif-spekulatif yang dituangkan dan diuji secara induktif-empirik atau pragmatik (Daliman, 2012: 51). Tahap heuristik banyak menyita waktu, biaya, tenaga, pikiran, dan juga perasaan. Sehingga itu agar dapat mengatasi masalah kesulitan sumber, maka kita harus menggunakan strategi untuk dapat mengatur segala sesuatunya baik mengenai biaya maupun waktu (Sjamsudin, 2012: 67 - 68).

Pada penelitian ini, sumber yang digunakan sebagian besar berasal dari hasil-hasil penelitian yang telah dicetak dalam bentuk buku ataupun jurnal, baik menyangkut lokalitas Gorontalo maupun Indonesia secara keseluruhan, diantaranya yakni buku yang ditulis oleh Hasanuddin et.al yang berjudul Sejarah 
Pendidikan di Gorontalo, selanjutnya buku dari Apriyanto dan Pinau yang berjudul dari Gorontalo untuk Indonesia: Sejarah Heroik Patriotik 23 Januari 1942. Kemudian buku dari Deliar Noer yang berjudul Gerakan Modern Islam di Indonesia 1900 - 1942, serta beberapa buku lainnya. Berikutnya, rujukan lain diambil dari hasil penelitian yang diterbitkan di Jurnal, diantaranya yakni tulisan dari Huda yang berjudul "Peran Pendidikan Islam Terhadap Perubahan Sosial”, dalam Edukasia: Jurnal Penelitian Pendidikan Islam, Vol 10, No. 1, Februari, dan tulisan dari Nur tentang Relasi Gender dan Pendidikan Islam, dalam Jurnal Pendidikan Islam, Vol. III, No. 2, Desember.

Langkah kedua yaitu kritik sumber yakni upaya untuk mendapatkan otentisitas dan kredibilitas sumber dengan cara melakukan kritik. Kritik dilakukan dengan memakai kerja intelektual dan rasional dan mengikuti metodologi sejarah guna mendapatkan obyektifitas suatu kejadian (Gottschalk dkk dalam Pranoto, 2010: 35). Selanjutnya kritik sumber itu terdiri dari kritik eksternal yang mengarah pada relasi antar sumber, dan kritik internal yang mengacu pada kredibilitas sumber (Pranoto, 2010: 36 - 37). Ketiga yaitu Interpretasi yang merupakan penafsiran atau pemberian makna terhadap fakta-fakta $(f a c t)$ dan bukti-bukti (evidences). Interpretasi sangat menentukan model pendekatan penelitian dan juga dalam upaya historiografi.

Tahap keempat yaitu tahap historiografi, ini merupakan tahap terakhir dari penelitian sejarah, dimana semua sumber yang telah menjadi fakta setelah melalui kritik, kini dieksplanasikan dengan interpretasi penulis menjadi historiografi yang naratif, deskriptif, maupun analitis. Daliman (2012: 99) mengatakan bahwa penulisan sejarah (historiografi) menjadi sarana mengkomunikasikan hasil-hasil penelitian yang diungkap, diuji (verifikasi) dan interpretasi. Rekonstruksi akan menjadi eksis apabila hasil-hasil penelitian tersebut ditulis. Dalam tulisan ini, bentuk penjelasan atau eksplanasi disajikan tidak hanya dalam bentuk narasi, melainkan dalam bentuk analisis secara kritis dan holistik. 


\section{B. Pembahasan}

Bagian pembahasan akan dibagi menjadi 2 bagian yakni pertama membahas tentang pendidikan Islam di Gorontalo awal abad ke-20, kedua, organisasi-organisasi Islam sebagai simbol perjuangan kemanusiaan.

\section{Dinamika Pendidikan Islam di Gorontalo Awal Abad XX}

Perkembangan pendidikan Islam pada periode awal abad XX merupakan impact dari sebuah kebijakan pemerintah kolonial Belanda saat itu yang dikenal dengan sebutan politik etis. Awal dari semua perubahan yang terjadi pada awal abad XX di HindiaBelanda (sekarang Indonesia) secara formal kenegaraan berasal dari adanya kebijakan politik etis oleh Belanda melalui pidato ratu Belanda pada tahun 1901 yang mengatakan bahwa "negeri Belanda memiliki kewajiban untuk mengupayakan kemakmuran, perkembangan sosial dan ekonomi pribumi di Hindia-Belanda" (Hardjosatoto, 1985: 95). Implementasi politik etis tersebut melalui pengembangan industri untuk kepentingan pribumi dan memperbesar penghasilan pertanian dengan cara menambah dan memperbaiki sistem irigasi. Selain itu, masalah kelebihan penduduk menjadi perhatian sehingga perlu adanya program transmigrasi (Niel, 2009: 56 - 57). Selanjutnya, van Devender mengatakan bahwa usaha-usaha perbaikan kehidupan kaum pribumi akan sia-sia jika dalam prakteknya tidak diimbangi dengan kualitas sumber daya manusia di kalangan pribumi yang memadai. Sehingganya bidang pendidikan juga harus mendapatkan perhatian (Niel, 2009: 58). Dengan demikian, maka kesempatan untuk mendapatkan akses pendidikan bagi penduduk pribumi menjadi terbuka, termasuk juga pendidikan Islam yang semakin modern.

Awal abad XX merupakan periode dimana pendidikan Islam mulai mengadopsi sistem pendidikan modern yang diperkenalkan oleh Belanda. Mulai saat itu, sistem pesantren dalam pendidikan Islam secara gradual bertransformasi menjadi madrasah. Tarmi (2001: 209) mengatakan bahwa madrasah merupakan kontinuitas dari sistem pendidikan tradisional yang dilakukan di rumah-rumah, langgar, rangkang, surau, mesjid, pesantren, 
dan sebagainya. Menurut Maksum latar belakang pertumbuhan madrasah di Indonesia secara umum disebabkan oleh 2 (dua) situasi yakni adanya gerakan pembaruan Islam di Indonesia, dan adanya respon pendidikan Islam terhadap kebijakan pendidikan pemerintah Belanda (Amirwan, 2013: 262).

Selain pada kelompok pembaruan Islam, madrasah juga mulai diterapkan pada pendidikan Islam kelompok tradisional. Latif (2013: 218) mengatakan bahwa dengan terjadinya modernisasi sekolah-sekolah tradisional, telah berdampak pada munculnya kemampuan kelompok tradisional untuk menghadapi tantangan dari kelompok reformis-modernis. Tidak hanya itu, kemampuan beradaptasi tersebut juga berdampak pada meningkatnya jumlah siswa pesantren secara signifikan. Hal ini kemudian secara perlahan-lahan memperkecil ruang dikotomi antara kelompok reformis-modernis dengan kelompok tradisional Islam.

Di wilayah Gorontalo sendiri, madrasah berkembang dengan pesat, dan menjadi alternatif kelompok-kelompok kecil masyarakat yang tidak mampu masuk dalam pendidikan barat. Muhammadiyah menjadi salah satu organisasi keagamaan yang berkontribusi besar dalam perkembangan madrasah di wilayah Gorontalo sampai ke wilayah-wilayah perkampungan. Menurut Lapidus upaya Muhammadiyah yang utama adalah pembentukan pola pendidikan modern sekolah agama (Lapidus,1999: 329). Pada tahun 1933 Muhammadiyah Gorontalo mendirikan Madrasah Ibtidaiyah di kampung Padebuolo, tahun 1934 di kampung Bugis, dan tahun 1935 di kampung Bulotadaa, Pilolodaa, dan Potanga. Tahun 1936 di kampung Wongkaditi, tahun 1937 di kampung Siendeng, kampung Bugis, Butajo-Potanga, Dembe I, dan tahun 1940 di kampung Tenda. Selain di wilayah Kota Gorontalo tersebut, Muhammadiyah juga mendirikan Madrasah Ibtidaiyah di luar wilayah Kota Gorontalo yakni di Limboto antara lain di Bolihuangga, Pone, Dehuwalolo, Bua-Batudaa, PadebuoloKabila, Kabila, Pentadio (Talaga), Suwawa, Batudaa, Bongomeme, Kwandang, Sumalata, Botumoito, Tilamuta, Talumopatu-Tapa, Marisa, Popayato, Lemito-Wanggarasi, dan Atinggola. Semuanya didirikan pada tahun 1937 (Hasanuddin et.al, 2012: 77 - 78). 
Menurut Polontalo sebagaimana di kutip Hasanuddin, meskipun terjadi perkembangan pesat dari madrasah-madrasah yang didirikan oleh Muhammadiyah, namun bukan berarti semuanya tanpa tantangan yang berarti. Salah satu permasalahan yang dihadapi Muhammadiyah adalah kurangnya tenaga pengajar sebab kebanyakan lulusan tenaga pengajar yang ada telah diserap pada pendidikan sekolah yang didirikan oleh Belanda. Untuk menghadapi permasalahan tersebut, Muhammadiyah Gorontalo kemudian mengajukan permohonan bantuan guru-guru agama Islam dari Yogyakarta pada tahun 1931. Dengan demikian, maka pengurus pusat Muhammadiyah mengirim utusan guru agama Islam seperti Abdur Rauf, Sutuhardjo, Harnu Dahlan, dan Abdullah Siraj. Pada tahun berikutnya yakni tahun 1932, pengurus pusat Muhammadiyah kembali mendatangkan tenaga pengajar seperti Basir Maksum dan Mohammad Dahlan. Selanjutnya pada tahun 1933 kembali mendatangkan tenaga pengajar yakni Raden Himan dan Abdul Hayat (Hasanuddin, et.al. 2012: 78 - 79).

Selain mengajukan bantuan guru-guru Islam dari Yogyakarta, Muhammadiyah cabang Gorontalo juga mengirim utusan putra-putra daerah untuk melanjutkan studi ke Yogyakarta. Ekspektasi dari program ini adalah untuk mengatasi kekurangan guru di sekolah-sekolah Muhammadiyah, dan juga untuk menciptakan kader Muhammadiyah secara berkelanjutan. Umumnya mereka ditempatkan di sekolah-sekolah seperti Kweeksernal Muhammadiyah, AMS Muhammadiyah, Wustho Kweekschool Muhammadiyah di Yogyakarta, dan HIK di daerah Solo. Pengiriman putra-putra daerah Gorontalo untuk belajar di Yogyakarta telah dimulai sejak tahun 1935 sampai dengan 1938 (Hasanuddin, et.al. 2012: 79).

Selain Muhammadiyah, terdapat pula organisasi Islam lainnya yang turut serta dalam mengembangkan pendidikan Islam di daerah Gorontalo, yakni Jong Islamieten Bond yang pada tahun 1931 mendirikan sekolah di kampung Ipilo, dan dipelopori oleh Hs. Laya, Dj. Arbie, dan Abubakar. Sekolah yang didirikan oleh organisasi Islam tersebut bertujuan untuk memperdalam pengetahuan Islam dan juga dalam rangka membendung 
pendidikan barat yang dipelopori oleh pemerintah kolonial Belanda (Hasanuddin, et.al. 2012 : 82).

Organisasi lainnya yang memberikan perhatian dalam dunia pendidikan adalah keturunan Arab di Gorontalo. Mereka mendirikan Madrasah Al Falah (awalnya bernama Madrasatul Fathil Arabiyah) yang didirikan oleh Umar Basalamah pada tahun 1929 di Gorontalo. Umumnya, murid-murid sekolah tersebut adalah warga keturunan Arab di Gorontalo. Dalam kurikulum Madrasah Al Falah, pengajarannya antara lain lughat, tarikh, fiqih/ ushul fiqih, imla' /khat, mufradat, nahwu/sharaf, ushul hisab, dan tafsir Alquran. Tenaga pengajarnya antara lain Sayyid Muhammad bin Umar Bahmid, Sayyid Ahmad bin Alwi Almasyur, Sayyid Salim bin Umar Bahmid, Abdullah bin Umar Assagaf, dan Abdullah bin Saleh Azzubedi. Pada tahun 1936, Madrasah Al Falah telah menamatkan beberapa murid diantaranya adalah Abas Rauf, Podungge, Abud Basalamah, Salim bin Umar Basalamah, Abdul Karim Badjeber, dan Abdul Bar Helingo. Perkembangan pendidikan dari kalangan Arab mendorong terbentuknya Partai Arab Indonesia di Gorontalo pada tahun 1937 yang dipelopori oleh Abdullah Jibran (Hasanuddin et.al. 2102: 80 - 82).

Perkembangan pendidikan yang dipelopori oleh organisasi Islam seperti Muhammadiyah, Jong Islamieten Bond, dan keturunan Arab telah mendorong Nahdatusysyafiyah mendirikan lembaga pendidikannya. Pada tahun 1935 organisasi tersebut mendirikan Syafiyah School Ipilo, Syafiyah School Ternate, Syafiyah School Potanga, Syafiyah Kweekschool Gorontalo yang diperuntukkan bagi calon pendidik di Madrasah Alwataniyah Gorontalo, Madrasah Al Falah Gorontalo, dan Kursus Azzakirah Potanga (Yayasan 23 Januari 1942 dan IKIP Negeri Manado, 1981: 36). Perkembangan pendidikan Islam di Gorontalo yang sebagian besar dan bahkan sepenuhnya dipelopori oleh organisasi-organisasi Islam, menjadi fondasi kuat dalam gerakan-gerakan perjuangan kemerdekaan di Gorontalo pada periode-periode selanjutnya.

Perkembangan pendidikan Islam di Indonesia pada umumnya, dan Gorontalo pada khususnya seperti yang dijelaskan di atas, dilatarbelakangi oleh beberapa faktor. Secara umum, terdapat 3 faktor utama yang mendorong perkembangan pendidikan Islam 
di Gorontalo pada awal abad ke XX. Pertama yakni semakin terbukanya akses pendidikan, transportasi, dan informasi bagi penduduk pribumi Gorontalo. Pada awal pembahasan sub-bab ini, telah dikatakan bahwa perkembangan pendidikan Islam di Gorontalo pada awal abad XX merupakan impak dari kebijakan politik etis yang diterapkan oleh pemerintah kolonial Belanda. Terkait dengan implementasi politik etis, Vickers (2011: 26) mengatakan bahwa kebijakan ini adalah untuk modernisasi kaum pribumi. Namun, apapun bentuk kemajuan yang akan dicapai dari interpretasi-interpretasi yang ada, dasar dari koloni tetaplah sama yakni laba. Meskipun demikian, Kartodirdjo (1988: 196 - 197) mengatakan bahwa keterbukaan akses pendidikan bagi kaum pribumi tetap berdampak signifikan terhadap kemunculan elit modern baru yang memiliki kesadaran demokrasi dan persamaan nasib semua bangsa. Selanjutnya, perkembangan media transportasi dan informasi juga memberikan sumbangsih yang besar dalam perkembangan pendidikan Islam. Semenjak perkembangan KPM (Koninklijke Paketvaart Maatschappij) pada dasawarsa awal abad XX, jaringan transportasi laut Gorontalo telah terbuka. Tercatat ada 2 rute pelayaran yang melewati Gorontalo yakni rute Singapura-Jawa-Makassar-Balikpapan-Sulawesi UtaraManado-Gorontalo-Ternate, dan juga rute Makassar-Pantai Timur Sulawesi-Banggai-Gorontalo-Teluk Tomini (Padmo, 2013: 160). Dengan demikian, maka perkembangan pendidikan Islam di Jawa yang merupakan pusat dari gerakan organisasi-organisasi Islam telah mudah diproliferasikan (disebarluaskan) ke daerah Gorontalo. Tidak hanya transportasi sub-nasional (dalam wilayah Indonesia), keterbukaan akses transportasi dengan negara-negara Islam lainnya seperti Arab Saudi dan Mesir menjadi penentu perkembangan pendidikan Islam di Indonesia secara umum. Gelombang haji yang semakin masif karena keterbukaan akses transportasi ke Arab Saudi menjadi momen perjumpaan elit-elit religius Indonesia dengan pemikiran-pemikiran baru dari lintas teriotorial. Stoddard (1966: 47) mengatakan bahwa ibadah haji merupakan salah satu anasir dalam pembentukan solidaritas Islam, dan juga instrumen penyebaran kebangkitan Islam di berbagai negara, termasuk Indonesia. 
Faktor kedua yang mendukung perkembangan pendidikan Islam di Indonesia (khususnya Gorontalo) adalah pandangan Islam tentang pentingnya ilmu. Islam memberikan perhatian yang istimewa terhadap ilmu pengetahuan dan juga aktivitas ilmiah. Pembuktiannya terlihat pada ayat yang pertama kali diwahyukan kepada Nabi Muhammad SAW adalah surah Al-'Alaq yang berbunyi: "Bacalah, dengan [menyebut] nama Tuhanmu, yang telah menciptakan” (Kosim, 2008: 122). Selain itu, dalam pandangan Islam, tidak ada pertentangan antara agama dan ilmu pengetahuan. Dalam batas-batas tertentu, seorang muslim akan bersedia menerima kebenaran yang ditemukan oleh ilmu pengetahuan. Meskipun demikian, bukanlah berarti kebenaran tersebut adalah hal yang mutlak. Oleh sebab itu, seorang muslim bukan hanya bersedia menerima namun juga akan memilih (Soedewo, 2007: 23).

Berdasarkan anjuran dalam Alquran tentang pentingnya ilmu pengetahuan bagi manusia tersebut, maka semangat untuk berpengetahuan umat muslim yang berada di Gorontalo pada awal abad ke-20 mengarah pada modernisasi. Hal ini dilakukan sebagai langkah adaptasi terhadap perkembangan ilmu pengetahuan yang pada era itu banyak mendapatkan pengaruh dari Belanda. Meskipun kebijakan pembukaan kesempatan pendidikan bagi pribumi mulai diterapkan pada dekade awal abad ke-20, namun dalam prakteknya terdapat diskriminasi dimana anak-anak pribumi Gorontalo yang secara genealogis merupakan keturunan bangsawan, mendapatkan prioritas utama dalam pendidikan barat. Praktek-praktek tersebut yang mengilhami elite-elite agama untuk kemudian membuka lembaga-lembaga pendidikan Islam yang diperuntukkan kepada kelompok masyarakat yang tidak termarginalisasi. Selain itu, pendidikan Islam juga bertujuan untuk memperkuat pemahaman tentang Islam, yang pada gilirannya menuju pada kesadaran untuk keluar dari praktek kolonialisme saat itu.

Faktor ketiga adalah masifnya penyebaran agama kristen oleh pemerintah Belanda. Jika gerakan nasionalisme Indonesia merupakan antitesis dari praktek kolonialisme seperti yang dikatakan oleh Kartodirdjo (2014:301-302), maka perkembangan 
pendidikan Islam di Gorontalo pada awal abad ke-20 merupakan antitesis dari masifnya gerakan evangelisme (penyebaran ajaran Protestan) di Gorontalo. Tercatat pada bulan Desember tahun 1905, umat Kristen Protestan mendirikan sekolah-sekolah salah satunya yakni Christelyke Maesa School setingkat Sekolah Desa di Kampung Tenda, Kota Gorontalo. Sekolah ini didirikan oleh H.M. Makalew dan R.M.H. Modjo, dan didukung sepenuhnya oleh pemerintah kolonial Belanda (Hasanuddin et.al, 2012: 76).

Memang dalam mengimplementasikan kebijakan politik etis yang salah satunya adalah perkembangan pendidikan, terdapat praktek diskriminasi dari pemerintah kolonial Belanda. Sekolahsekolah Kristen mendapatkan perhatian khusus dan bahkan bantuan finansial yang tidak sedikit, sementara itu, sekolahsekolah Islam justru diperlakukan sebaliknya. Bahkan pemerintah kolonial Belanda mengeluarkan kebijakan yang dikenal dengan ordonansi guru sebanyak 2 kali yakni pada tahun 1882 dan 1925. Peraturan itu bertujuan untuk melakukan pengawasan yang ketat terhadap praktik pendidikan Islam. Guru-guru yang mengajar di sekolah-sekolah Islam harus mendapatkan izin dari pemerintah kolonial. Bahkan pada tahun 1935 pemerintah kolonial Belanda mengeluarkan ordonansi sekolah liar, dan membubarkan beberapa sekolah madrasah yang tidak memiliki izin (Nata, 2011: 285). Tindakan represif dari pemerintah kolonial Belanda terhadap sekolah-sekolah Islam, serta adanya agenda gerakan evangelisme justru menjadi pemicu perkembangan pendidikan Islam dan akhirnya bertransformasi menjadi pendidikan modern secara gradual.

Transformasi pendidikan Islam dari tradisional menjadi modern pada awal abad XX, berimplikasi pada munculnya gerakan-gerakan humanisasi di kalangan umat Islam Gorontalo yang berafiliasi ke dalam organisasi-organisasi Islam. Selain disimbolkan sebagai perjuangan pergerakan nasional, organisasiorganisasi Islam juga merupakan simbol perjuangan kemanusiaan. Artinya bahwa tujuan organisasi-organisasi Islam di Gorontalo yang merupakan perluasan dari Jawa, berorientasi pada perkembangan manusia Indonesia menjadi lebih bermartabat dengan jalan yang berbeda-beda. Ada yang berorientasi pada 
gerakan politik, ada juga yang berorientasi pada gerakan-gerakan sosial seperti pendidikan. Kesemuanya merupakan bagian dari perjuangan kemanusiaan.

\section{Organisasi-Organisasi Islam di Gorontalo: Simbol Perjuangan Kemanusiaan}

Terjalinnya komunikasi dan terbukannya jalur transportasi antara Gorontalo dengan pulau Jawa telah mempermudah proliferasi (penyebarluasan) organisasi-organisasi dari pulau Jawa ke daerah Gorontalo, termasuk organisasi Islam yakni Sarekat Islam dan Muhammadiyah. Sarekat Islam yang pada awal berdirinya bernama Sarekat Dagang Islam, merupakan transformasi dari Rekso Roemekso yakni sebuah organisasi ronda yang bertugas mengawasi keamanan daerah. Kelompok ini didirikan pada tahun 1912 oleh Haji Samhudi di Surakarta. Namun saat diperiksa oleh kepolisian Hindia-Belanda, organisasi ini kemudian mengaku sebagai cabang Sarekat Dagang Islam (SDI) Bogor yang didirikan oleh Tirtoadhisoerjo (Shiraishi, 1997: 55 - 56).

Awalnya, organisasi ini adalah perkumpulan para pedagang Islam di wilayah Jawa yang dikenal dengan nama Sarekat Dagang Islam (SDI). Mengenai tokoh pendirinya, terdapat perdebatan yang serius antara Tirto Adi Suryo dan Samanhudi yang samasama mengklaim bahwa masing-masing dari mereka adalah pendiri organisasi tersebut (Niel, 2009: 136). Tirto Adi Suryo sendiri dalam tulisan Toer (1985) dikatakan sebagai tokoh pergerakan nasional yang sengaja didiskreditkan oleh Belanda karena sikap yang radikal dalam menentang Belanda.

Organisasi Sarekat Islam (SI) di wilayah Gorontalo lebih dikenal dengan nama organisasi sarekat. SI memiliki seorang pemimpin yang kharismatik dan memiliki pengaruh yang besar yakni H.O.S. Cokroaminoto. Karena pengaruhnya yang besar khususnya di tanah Jawa, Cokroaminoto diberi julukan "Raja Jawa tanpa mahkota” dan juga “ Jang Utama”. Tidak hanya itu, pidatonya yang lantang dan penuh semangat setiap dalam pertemuan yang diadakan oleh SI membuat dia dijuluki sebagai "singa podium". Cokroaminoto pula yang menjadi orang pertama yang mendengungkan secara terbuka tentang zelfbestuur 
(pemerintahan sendiri) untuk Indonesia (Mulawarman, 2015: 1-13). Pemikiran-pemikiran Cokroaminoto banyak ditemukan dalam tulisan-tulisannya. Salah satu pemikiran yang cukup dikenal sampai sekarang adalah tentang sistem kemasyarakatan yang sosial-religius dengan susunan pemerintahan yang bersendikan demokrasi dan musyawarah mufakat (Tjokroaminoto, 2010: 13).

Kedatangan H.O.S. Cokroaminoto di Gorontalo pada tahun 1923 telah membantu penyebaran organisasi SI di wilayah Gorontalo, sehingga pada tahun 1928 organisasi Sarekat Islam resmi didirikan di Gorontalo (Hasanuddin dan Amin, 2012: 199). Tokoh Sarekat Islam yang terkenal di tanah Gorontalo antara lain yakni Karel Ponamon dan Jusuf Sabah (Yayasan 23 Januari 1942 dan IKIP Negeri Manado, 1981: 34). SI di daerah Gorontalo melakukan beberapa kegiatan bidang sosial diantaranya mendirikan sekolah-sekolah, asrama-asrama, serta media. Selain itu, SI yang dikemudian hari berkembang menjadi Partai Sarekat Islam (PSI) juga turut dalam menggembleng pendidikan politik di masyarakat melalui pidato-pidato yang tidak jarang mengkritisi praktek kolonialisme Belanda. Pada tahun 1931 dan 1932 terjadi bentrokan dengan pemerintah Belanda di masjid Jami (sekarang menjadi masjid Baiturrahim di Kota Gorontalo), yang disebabkan oleh pidato-pidato yang keras dari tokoh-tokoh PSI (Apriyanto dan Pinau, 2013: 46). SI memang merupakan salah satu organisasi yang saat itu memiliki gerakan cukup keras menentang Belanda.

Organisasi lainnya yang menggunakan Islam sebagai anasir pembentukannya yakni Muhammadiyah. Tujuan organisasi Muhammadiyah pada prinsipnya selain dipengaruhi oleh gerakan pembaruan Islam, juga dilatarbelakangi oleh kondisi sosial budaya, ekonomi maupun politik yang dihadapi masyarakat muslim pada masa itu (Majelis Diktilitbang dan LPI PP Muhammadiyah, 2010: 38). Pada tanggal 18 November 1928 , organisasi Muhammadiyah di wilayah Gorontalo berdiri dan diresmikan oleh Mohammad Junus Anis selaku sekretaris umum pimpinan pusat Muhammadiyah. Pendirian organisasi Muhammadiyah di Gorontalo tidak lepas dari peran Jusuf Otoluwa (salah seorang siswa keguruan di Jakarta) yang mengajak temantemannya untuk mendirikan sebuah organisasi Muhammadiyah 
yang saat itu cukup berkembang. Muhammadiyah dengan cepat berkembang bukan hanya di daerah Gorontalo melainkan juga di wilayah sekitarnya seperti Sulawesi Tengah (Apriyanto dan Pinau, 2013: 49). Tokoh-tokoh lainnya yang turut memberikan sumbangsih dalam perkembangan Muhammadiyah antara lain Tom Olil (ketua cabang Muhammadiyah yang pertama), U.H. Buluati, I Bada, H Akase, Muhammad Dunggio, Haji Jusup Abas, dan Muhsin Muhamad (Hasanuddin dan Amin, 2012: 200).

Kegiatan Muhammadiyah yang berorientasi pada aspek sosial turut membantu dalam perkembangan organisasi itu sendiri, sebab mendapatkan simpati dari rakyat Gorontalo. Kegiatan dakwah, kemudian pengembangan pendidikan dan kesehatan untuk masyarakat Gorontalo merupakan prioritas Muhammadiyah. Dakwah yang dijalankan Muhammadiyah adalah untuk melawan praktek evangelisme Kristen oleh Belanda dan tahayul-tahayul yang masih berkembang di masyarakat. Selain itu, pendidikan Islam, pembangunan mesjid, rumah sakit, dan tamantaman pengajian terus dikembangkan. Dan pada tahun 1930 Muhammadiyah membentuk Aisyiyah (wadah kaum perempuan) yang kepengurusannya terdiri dari Marie Lamadilawo, Marie Dambea, Ida Dunda, N.J. Latifah Kamba, Hadidjah Husa, Noni Arbie, Zubaidah Dungga, dan Marie Suleman. Selanjutnya, Muhammadiyah juga mendirikan Balai Kesehatan yang terletak di Kota Gorontalo dengan binaan dari Dokter Sunaryo dari Yogyakarta. Pendirian Balai ini bertujuan untuk memenuhi kebutuhan palayanan kesehatan penduduk (Hasanuddin dan Amin, 2012: 200-202).

Selain Sarekat Islam dan Muhammadiyah, di Gorontalo juga berdiri organisasi keagamaan lainnya (Islam) yakni Nahdatussyafiyah yang cukup pula mendapat simpati dari masyarakat Gorontalo. Pada tahun 1935 organisasi ini diperkenalkan oleh Salim bin Djindan dalam upaya untuk mengembangkan dan menegakkan ajaran Islam melalui kegiatan sosial seperti pendidikan, dan gerakan sosial. Meskipun sumbersumber mengenai organisasi ini belum cukup memadai, namun eksistensinya dapat ditelusuri dengan terbentuknya rantingranting di kampung-kampung, serta mendirikan sekolah-sekolah 
diantaranya yakni Syafiyah School Ipilo, Syafiyah School Potanga, Syafiyah Kweekschool Gorontalo, Madrasah Alwathaniyah dan kursus Azzakirah Potanga (ANRI dalam Apriyanto dan Pinau, 2013: 51).

Organisasi lainnya yang juga menyebar sampai ke wilayah Gorontalo adalah Persatuan Islam (PERSIS). Organisasi ini didirikan di Bandung pada tahun 1920-an oleh Ahmad Hassan dan Mohammad Natsir. Pada umumnya gerakan PERSIS kurang memberikan tekanan pada kegiatan organisasi, termasuk penyebarannya dan juga kaderisasinya. Meskipun demikian, pengaruhnya jauh lebih besar dari pada perluasan organisasinya (Noer, 1982: 96-97). PERSIS masuk ke wilayah Gorontalo melalui beberapa tokoh diantaranya adalah A.R. Ointu. Selain PERSIS, juga terbentuk organisasi Penyadar di wilayah Gorontalo. Penyadar adalah organisasi yang didirikan oleh $\mathrm{H}$. Agus Salim sebagai akibat dari perbedaan pendapat dengan H.O.S. Cokroaminoto tentang sikap perjuangan yang kooperatif dan non-kooperatif dengan Belanda. Dalam upaya mendirikan organisasi ini, H. Agus Salim dibantu oleh rekannya yakni Mr. Moh. Room (Yayasan 23 Januari 1942 dan IKIP Negeri Manado, 1981: 37). Pada prinsipnya, perkembangan organisasi-organisasi Islam di Indonesia (termasuk Gorontalo) pada periode awal abad ke-20, merupakan respon perlawanan terhadap langkah-langkah pemerintah Belanda untuk mengembangkan agama Kristen.

Sementara itu, pemuda-pemuda yang ada di daerah Gorontalo seperti A.R. Ointu, U.H. Buluati, juga membentuk perkumpulan pemuda yang menggunakan Islam sebagai anasir pemersatu. Organisasi tersebut adalah Jong Islamieten Bond (Habibie et.al. 2004 : 39). Jong Islamieten Bond (JIB) merupakan organisasi baru yang didirikan oleh orang-orang yang keluar dari Jong Java. Adapun tujuan dari JIB adalah untuk memajukan pengetahuan Islam, hidup secara Islam, dan persatuan dalam Islam (Pringgodigdo, 1994: 120). Mereka menggerakkan jiwa dan semangat pemuda melalui kegiatan-kegiatan Islam seperti tablig-tablig, peringatan hari besar Islam, musyawarah dan dakwah-dakwah. Jong Islamieten Bond cabang Makasar didirikan oleh kaum pelajar yang bersekolah di OSVIA Makasar antara lain 
Ismail Datau, Syam Biya, Abdullah Amu, dan Anyone Hadju. Pada pertemuan pertama mereka membentuk susunan pengurus yakni Djafar Arbie (ketua), Husain Laiya (wakil ketua), Tjan Lamato (sekretaris), Marie Mantu (bendahara). Gerakan JIB di wilayah Gorontalo tergolong cukup keras. Terlihat dari rapat umum yang diadakan di Bioskop Murni Gorontalo dimana Giu Thanib membawakan ceramah tentang Islam dan cita-cita kemerdekaan, yang berujung pada tindakan represif pemerintah kolonial Belanda dimana beberapa anggota JIB dibawa ke tangsi polisi (Yayasan 23 Januari 1942 dan IKIP Negeri Manado, 1981: 37 - 38).

Selain perkumpulan-perkumpulan pemuda, di Gorontalo juga terbentuk gerakan kepanduan yang menjalankan prinsip kaderisasi. Keanggotaan gerakan kepanduan berasal dari mereka yang bersekolah di sekolah rakyat, sekolah menengah, orang dewasa, sampai ke golongan orang tua. Gerakan-gerakan kepanduan yang saat itu muncul di daerah Gorontalo adalah Sarekat Islam Afdeling Pandu (SIAP) dari Sarekat Islam, Hizbul Wathon dari Muhammadiyah, National Islamitische Padvinderij (Natipi), Jong Islamieten Bond Dames Afdeling (JIBDA) dari Jong Islamieten Bond (Habibie et.al. 2004: 39-40), serta Pandu Anshor dari Nahdatusysyafiiyah (ANRI dalam Hasanuddin dan Amin, 2012: 205). Organisasi-organisasi kepanduan tersebut memang merupakan bagian dari gerakan organisasi-organisasi Islam yang saat itu berkembang di Indonesia.

Selain organisasi-organisasi Islam, kebangkitan pergerakan Islam di Indonesia pada periode awal abad ke-20 disertai juga dengan seruan-seruan melalui media masa atau pers. Salah satu pers yang intens dalam menyuarakan kemajuan bagi bangsa dan tanah air yang didasarkan pada Islam adalah surat kabar Oetoesan Islam. Surat kabar ini terbit sebanyak 2 kali dalam sebulan di Gorontalo (Surjomihardjo, 2002: 110). Hal ini menunjukkan bagaimana kesadaran perjuangan aspek kemanusiaan tumbuh di kalangan Islam di Gorontalo. Kesadaran tersebut digembleng melalui pendidikan Islam, dan dimanifestasikan dalam perjuangan organisasi-organisasi Islam dan juga pers. Ajaran Islam tentang kemanusiaan dijadikan sebagai instrumen penting dalam menghadapi kekuatan kolonialisme Belanda yang dipandang 
bertentangan dengan nilai-nilai kemanusiaan, karena terdapat unsur-unsur diskriminasi.

Gerakan-gerakan agama yang dilakukan pada periode awal abad ke-20 di Gorontalo seperti penjelasan di atas, merupakan implementasi dari kesadaran kemanusiaan yang diperoleh dari pendidikan, terutama pendidikan Islam. Pendidikan Islam memiliki korelasi dengan dunia politik, sehingga memicu gerakangerakan perlawanan terhadap status quo yang dinilai saat itu jauh dari praktek-praktek yang humanis. Supriyanto (2001: 270) mengatakan bahwa salah satu aspek penting dalam pendidikan Islam adalah aspek politik. Pendidikan Islam memberikan penjelasan tentang bagaimana hubungan antara masyarakat dan pemerintah, sistem pemerintahan, hubungan antar negara, hubungan antar organisasi, dan sebagainya. Pada titik ini terjadi perjumpaan antara pendidikan Islam dengan pembentukan kesadaran politik yang menjadi fondasi pembentukan dan perkembangan organisasi-organisasi Islam.

Pembentukan organisasi-organisasi Islam di Gorontalo menggambarkan bagaimana gerakan agama tidak hanya menyentuh masalah kebenaran doktrin atau ajaran tetapi juga telah menyentuh masalah tatanan sosial (Abdullah, 1987: 5). Dalam perkembangannya, gerakan Islam melalui organisasi-organisasi Islam memiliki corak perjuangan yang beragam, sesuai dengan tujuan berdirinya organisasi. Meskipun sempat terjadi dikhotomi yang tajam antara Pan-Islamisme yang supranasional dengan nasionalisme modern, seperti yang dikatakan oleh Esposito (1990: 325), namun untuk sementara waktu, nasionalisme Indonesia oleh sebagian besar orang diterima sebab dianggap sebagai pemersatu elemen-elemen yang berbeda, termasuk kelompok-kelompok non-Islam. Adanya kekuatan kolonialisme Belanda yang dipandang sebagai musuh bersama, menjadi anasir penting dalam penyatuan tujuan gerakan yakni kemerdekaan rakyat Gorontalo. Bagi kelompok Islam, kemerdekaan dari praktek kolonialisme yang diskriminatif dan tidak jarang juga menjadi represif, merupakan perjuangan untuk kemanusiaan. Dalam pandangan Ibnu Khaldun (dalam Kasdi, 2015: 12) bahwa : 
“.... kekuasaan harus ada dalam masyarakat, untuk menjaga eksistensinya dan mengatur sistem interaksi muamalah antar mereka. Dalam konsepnya, kekuasaan harus didasari oleh 'ashabiyah (solidaritas), dimana sekelompok masyarakat yang mempunyai kesepakatan untuk mendirikan kekuasaan mempunyai komitmen yang sama. 'Ashabiyah ini bukan hanya karena pertalian darah, tetapi bisa dengan perjanjian, kesamaan nasib dan latar belakang ....."

Doktrin Islam tentang kemanusiaan yang berkeadilan dan berkeadaban yang disebarkan melalui pendidikan Islam oleh berbagai organisasi Islam di Gorontalo, telah berhasil menjadi pemicu dalam gerakan-gerakan perlawanan terhadap kolonialisme Belanda, meskipun berbeda-beda dalam pola perjuangan, namun tetap terdapat satu konsensus tentang sebuah kemerdekaan sebagai pintu gerbang penciptaan tatanan sosial yang berperikemanusiaan. Perjuangan meraih kemerdekaan dari organisasi-organisasi Islam, organisasi kepemudaan, dan organisasi yang nasionalis di Gorontalo menemukan momentumnya dan mencapai titik kulminasi perjuangannya pada peristiwa pengambilalihan kekuasaan dari pemerintah kolonial Belanda pada tanggal 23 Januari 1942. Sampai sekarang, masyarakat Gorontalo memperingati peristiwa tersebut sebagai hari kemerdekaan Gorontalo.

\section{Simpulan}

Awal abad ke-20 di Indonesia (termasuk Gorontalo), terjadi perubahan yang signifikan. Perkembangan pendidikan menjadi sorotan penting termasuk pendidikan Islam. Di wilayah Gorontalo, selain didirikan sekolah-sekolah pemerintah Belanda, juga didirikan sekolah-sekolah Islam yang dilaksanakan oleh organisasi-organisasi seperti Muhammadiyah, Sarekat Islam (SI), PERSIS, Nahdhatusysyafiyah, Jong Islamieten Bond, dan sebagainya. Sekolah-sekolah Islam tersebar sampai ke wilayahwilayah perkampungan. Pendidikan Islam yang diajarkan dalam sekolah-sekolah Islam tersebut pada perkembangannya tidak hanya menyentuh persoalan ajaran agama Islam, namun juga masuk pada perubahan tatanan sosial. 
Perkembangan pendidikan Islam di Gorontalo tidak lepas dari beberapa faktor yang mempengaruhinya. Pertama, terbukanya kesempatan akses pendidikan, transportasi dan juga informasi bagi penduduk pribumi (Gorontalo). Di awal abad ke-20, terjadi perubahan arah kebijakan politik pemerintah Belanda dari konservatis menjadi humanis. Pendidikan Islam pun banyak yang bertransformasi dari sistem tradisional menjadi modern. Faktor kedua adalah pandangan Islam terkait ilmu pengetahuan. Islam menempatkan ilmu pengetahuan sebagai sesuatu yang berharga bagi umat manusia. Pemahaman seperti inilah yang mendorong para tokoh-tokoh Islam yang berkesempatan berinteraksi dengan wilayah Islam lainnya seperti Mesir dan Arab Saudi untuk terus mencari dan bahkan menyebarkan ilmu pengetahuan di Indonesia. Faktor ketiga adalah semakin masifnya penyebaran ajaran Protestan yang didukung oleh pemerintah Belanda. Kegiatan evangelisme dari kaum misionaris Belanda banyak menggunakan pendidikan sebagai instrumennya, sehingga itu banyak sekolah-sekolah Kristen yang didirikan dengan sokongan dana yang cukup besar dari pemerintah Belanda. Menyadari hal tersebut, organisasi-organisasi Islam semakin memperkuat dan memperluas pendidikan Islam sebagai counter terhadap kegiatan evangelisme tersebut.

Perkembangan pendidikan Islam di wilayah Gorontalo, berdampak pada pembentukan kesadaran tentang perjuangan kemanusiaan. Menyadari adanya praktek penindasan yang dilakukan oleh pemerintah Belanda, rakyat Gorontalo melalui elite-elite lokalnya menggelorakan gerakan perlawanan terhadap status quo. Berbagai gerakan terus digalakkan baik di bidang politik, agama, sosial (termasuk pendidikan dan kesehatan), budaya, dan lainnya sebagai manifestasi dari kesadaran perjuangan kemanusiaan. Orientasi dari semua pergerakan tersebut adalah mencapai kemerdekaan Indonesia sebagai sebuah bangsa yang saat itu berada di bawah otoritas pemerintahan kolonial Belanda. 


\section{DAFTAR PUSTAKA}

Abdullah, Taufik. 1987. Pengantar : Islam, Sejarah, dan Masyarakat, dalam Abdullah, Taufik (ed). Sejarah dan Masyarakat: Lintasan Historis Islam di Indonesia, Jakarta: Pustaka Firdaus.

Apriyanto, Joni dan Pinau, Sri Wahyuni A. 2013. Dari Gorontalo

Untuk Indonesia: Sejarah Heroik Patriotik 23 Januari 1942, Yogyakarta: Ombak.

Amirwan. 2013. Kebangkitan dan Perkembangan Madrasah di Indonesia, dalam Nizar, Samsul et.al. Sejarah Sosial dan Dinamika Intelektual: Pendidikan Islam di Nusantara, Jakarta: Kencana Prenada Media Group.

Daliman, A. 2012. Metode Penelitian Sejarah, Yogyakarta: Ombak.

Esposito, John L. 1990. Islam dan Politik, Jakarta: PT. Bulan Bintang.

Freire, Paul. 1985. Pendidikan Kaum Tertindas, Jakarta: LP3ES.

Habibie, Sudirman et.al. 2004. 23 Januari 1942 dan Nasionalisme Nani Wartabone, Gorontalo: Dinas Pendidikan dan Kebudayaan Provinsi Gorontalo.

Hardjosatoto, Suhartoyo. 1985. Sejarah Pergerakan Nasional Indonesia : Suatu Analisa Ilmiah, Yogyakarta: Liberty Yogyakarta.

Hasanuddin, et.al. 2012. Sejarah Pendidikan di Gorontalo, Yogyakarta: Kepel Press.

Hasanuddin dan Amin, Basri. 2012. Gorontalo Dalam Dinamika Sejarah Masa Kolonial, Yogyakarta: Ombak.

Huda, Miftahul. 2015. Peran Pendidikan Islam Terhadap

Perubahan Sosial, dalam Edukasia : Jurnal Penelitian

Pendidikan Islam, Vol 10, No. 1, Februari: 165 - 188.

Kartodirdjo, Sartono. 1988. Modern Indonesia: Tradition \& Transformation: A Social-Historical Perspective, Yogyakarta: Gadjah Mada University Press. 
. 2014. Pengantar Sejarah Indonesia Baru Jilid II :

Sejarah Pergerakan Nasional, Yogyakarta : Ombak.

Kasdi, Abdurrahman. 2015. Pendidikan Sejarah dalam Perspektif

Pemikiran Ibnu Khaldun, dalam Edukasia : Jurnal Penelitian Pendidikan Islam, Vol. 10, No. 1, Februari : 1 -16 .

Kosim, Mohammad. 2008. Ilmu Pengetahuan Dalam Islam (Perspektif Filosofis-Historis), dalam Tadrîs, Vol 3, No. 2 : 121 - 140 .

Kuntowijoyo. 1991. Paradigma Islam: Interpretasi Untuk Aksi, Bandung: Penerbit Mizan.

Kurniawan, Syamsul dan Mahrus, Erwin. 2013 (cet. Ke-2). Jejak Pemikiran Tokoh Pendidikan Islam, Yogyakarta : ARRUZZ MEDIA.

Latif, Yudi. 2013. Genealogi Intelegensia : Pengetahuan dan Kekuasaan Intelegensia Muslim Indonesia Abad XX, Jakarta : Kencana Prenada Media Group.

Lapidus, Ira M. 1999. Sejarah Sosial Umat Islam, Jakarta: PT. RajaGrafindo Persada.

Majelis Diktilitbang dan LPI PP Muhammadiyah. 2010. 1 Abad Muhammadiyah: Gagasan Pembaruan Sosial Keagamaan, Jakarta: Penerbit Buku Kompas.

Masduki. 2015. Pendidikan Islam dan Kemajuan Sains: Historisitas Pendidikan Islam Yang Mencerahkan, dalam Jurnal Pendidikan Islam, Volume IV, Nomor 2, Desember :261-275.

Mulawarman, Aji Dedi. 2015. Jang Oetama: Jejak dan Perjuangan H.O.S. Tjokroaminoto, Yogyakarta: Galang Pustaka.

Mustaghfiroh, Hikmatul. 2015. Rekonstruksi Filsafat Pendidikan Islam, dalam Edukasia: Jurnal Penelitian Pendidikan Islam, Vol. 10, No. 1, Februari: 89 - 104.

Nata, H Abuddin. 2011. Sejarah Pendidikan Islam, Jakarta: Kencana Prenada Media Group. 
Niel, Robert van. 2009 (cetakan kedua). Munculnya Elite Modern Indonesia, Jakarta: Dunia Pustaka Jaya bekerjasama dengan Yayasan-Yayasan Ilmu Sosial.

Noer, Deliar. 1982. Gerakan Modern Islam di Indonesia 19001942, Jakarta: LP3ES.

Padmo, Soegijanto. 2013. Transportasi dan Komunikasi, dalam Abdullah, dan A.B. Lapian (eds). Indonesia Dalam Arus Sejarah Jilid V: Masa Pergerakan Kebangsaan, Jakarta : Ichtiar Baru Van Hoeve.

Pranoto, Suhartono Wiryo. 2010. Teori dan Metodologi Sejarah, Yogyakarta: Graha Ilmu.

Pringgodigdo, A.K. 1994. Sejarah Pergerakan Rakyat Indonesia, Jakarta: Dian Rakyat.

Rohmah, Nur. 2014. Relasi Gender dan Pendidikan Islam, dalam Jurnal Pendidikan Islam, Vol. III, No. 2, Desember: 345364.

Shiraishi, Takashi. 1997. Zaman Bergerak: Radikalisme Rakyat di Jawa, 1912 - 1926, (terjemahan Hilmar Farid), Jakarta: Pustaka Utama Grafiti.

Sjamsudin, Helius. 2012. Metodologi Sejarah, Yogyakarta: Ombak.

Soedewo. 2007. Islam dan Ilmu Pengetahuan, Jakarta: Penerbit Darul Kutubil Islamiyah.

Supriyanto. 2001. Pendidikan Islam dan Politik, dalam Nata, Abuddin dan Azra, Azyumardi (eds). Sejarah Pertumbuhan dan Perkembangan Lembaga-Lembaga Pendidikan Islam di Indonesia, Jakarta: Gramedia Widiasarana Indonesia bekerja sama dengan IAIN Jakarta.

Surjomihardjo, Abdurrachman. 2002. Beberapa Segi Perkembangan Sejarah Pers di Indonesia, Jakarta: Penerbit Buku Kompas.

Stoddard, Lothrop. 1966. Dunia Baru Islam, Jakarta: Panitia Penerbit Menko Kesedjahteraan Indonesia.

Tarmi. 2001. Kebangkitan dan Perkembangan Madrasah di Indonesia, dalam Nata, Abuddin (ed). Sejarah 
Pertumbuhan dan Perkembangan Lembaga-Lembaga Pendidikan Islam di Indonesia, Jakarta: Gramedia Widiasarana Indonesia bekerja sama dengan IAIN Jakarta Tjokroaminoto, H.O.S. 2010 (cetakan kedua). Islam dan Sosialisme, Bandung: Sega Arsy.

Toer, Pramoedya Ananta. 1985. Sang Pemula, Jakarta: Hasta Mitra.

Vickers, Adrian. 2011. Sejarah Indonesia Modern, Yogyakarta: Insan Madani.

Yayasan 23 Januari 1942 bekerja sama dengan IKIP Negeri Manado Cabang Gorontalo. 1981. Perjuangan Rakyat di Daerah Gorontalo, Menentang Kolonialisme dan Mempertahankan Negara Proklamasi, Jakarta : PT. Gobel Dharma Nusantara. 
